\title{
Kualitas Telur Puyuh yang Diberikan Ransum dengan Penambahan Silase Tepung Daun Ubi Kayu
}

\section{Quality of Quail Egg Fed Ration with Addition of Cassava Leaves Silage}

\author{
W. Satria, A. E. Harahap* dan T. Adelina \\ Program Studi Peternakan Fakultas Pertanian dan Peternakan, UIN Sultan Syarif Kasim Riau \\ Jl. H.R. Soebrantas No. 155 KM 15 Tuahmadani Tampan Pekanbaru 28293 \\ *Corresponding e-mail : neniannisaharahap@yahoo.co.id
}

\begin{abstract}
Egg is a product from the poultry which has a high nutrition value and easy to be digested. The research aimed to evaluate the impact of using silage of cassava leaves in a form of mash ration on the quail eggs. The experimental design consisted of 4 treatments and 4 replications. In addition, each replication consisted of 4 quails. The treatments were T0 (ration + silage of cassava leaves 0\%), T1 (ration + silage of cassava leaves 3\%), T2 (ration + silage of cassava leaves $6 \%$ ), T3 (ration + silage of cassava leaves $9 \%$ ). The parameters being observed were egg albumen index, egg yolk index, the egg weight and haugh unit value. The result of the research was the use of cassava leaves flour in quail formulation at $9 \%$ was not enough increase the index of egg albumen, egg yolk index, the egg weight and haugh unit value, yet the use of cassava leaves flour can gain the quails weight. Thus, the best treatment was at the rate $3 \%$ in which it is able to increase the index of egg albumen, egg yolk index and haugh unit value.
\end{abstract}

Key words: egg, albumen, yolk, silage, cassava, quail layer

\begin{abstract}
ABSTRAK
Telur adalah produk unggas yang mempunyai nilai gizi tinggi dan mudah dicerna. Penelitian bertujuan mengetahui pengaruh penggunaan silase tepung daun ubi kayu dalam ransum berbentuk mash terhadap kualitas telur puyuh. Penelitian menggunakan metode Eksperimen dengan Rancangan Acak Lengkap (RAL) terdiri dari: 4 perlakuan dan 4 kali ulangan, dan setiap ulangan terdiri dari 4 ekor burung puyuh. Perlakuan yang diberikan yaitu T0 (Ransum + silase tepung daun ubi kayu 0\%), T1 (Ransum + silase tepung daun ubi kayu 3\%), T2 (Ransum + silase tepung daun ubi kayu 6\%), T3 (Ransum + silase tepung daun ubi kayu 9\%). Parameter yang diamati indeks putih telur, indeks kuning telur, bobot telur, dan nilai haugh unit. Hasil penelitian ini menunjukkan bahwa penggunaan silase tepung daun ubi kayu dalam formulasi burung puyuh sampai $9 \%$ belum mampu meningkatkan indeks putih telur, indeks kuning telur dan nilai haugh unit tetapi dapat meningkatkan bobot telur puyuh. Perlakuan terbaik pada taraf 3\% karena dapat meningkatkan indeks putih telur, indeks kuning telur, dan nilai haugh unit.
\end{abstract}

Kata kunci : telur, putih telur, kuning telur, silase, ubi kayu, puyuh petelur

\section{PENDAHULUAN}

Peningkatan konsumsi protein bagi masyarakat penting dilakukan terutama bagi masyarakat yang tidak mampu membeli pangan asal hewan yang umumnya relatif mahal. Penganekaragaman konsumsi protein asal hewan perlu dilakukan untuk memenuhi kebutuhan hal tersebut. Salah satu upaya untuk memenuhi kebutuhan protein hewani pada masyarakat adalah usaha peternakan. Usaha peternakan yang memiliki nilai strategis di Indonesia khususnya dalam penyediaan protein hewani untuk memenuhi kebutuhan dalam negeri adalah usaha perunggasan (Abidin, 2003).
Upaya untuk penyediaan protein salah satunya terdapat pada telur. Telur mempunyai kandungan protein 12,7-13.9\% karena di dalamnya terdapat susunan asam amino esensial lengkap sehingga telur dijadikan patokan dalam penentuan mutu protein dalam berbagai bahan pangan. Protein yang terdapat pada telur mempunyai nilai gizi yang cukup tinggi untuk menambah stamina dan pertumbuhan anak-anak.

Ternak yang menghasilkan telur dan telah biasa diperdagangkan dan dikonsumsi manusia yaitu ayam, itik dan puyuh. Kebanyakan konsumen memilih telur ayam dan telur itik dibandingkan telur puyuh. Sebenarnya telur puyuh tidak kalah dengan telur unggas lainnya. 
ketersediaan telur dan daging puyuh dapat menambah variasi penyediaan sumber protein sehingga konsumen mempunyai lebih banyak pilihan.

Kandungan protein dan lemak telur puyuh lebih baik dibandingkan dengan telur unggas lainnya. Kandungan proteinnya tinggi $13,1 \%$, tetapi kadar lemaknya rendah $11,1 \%$. Secara umum, komposisi kandungan telur puyuh adalah $47,4 \%$ albumin (putih telur), 31,9\% yolk (kuning telur), serta $20,7 \%$ cangkang dan selaput tipis. Bobot telur puyuh rata-rata 10 gram atau sekitar $8 \%$ dari bobot tubuh puyuh betina (Listiyowati dan Rospitasari, 2009). Produksi dan kualitas telur puyuh dipengaruhi oleh pakan yang berkualitas.

Pakan merupakan faktor yang sangat penting dalam usaha peternakan karena memiliki kontribusi sebesar $70-80 \%$ terhadap keseluruhan biaya produksi. Pakan berfungsi untuk memenuhi kebutuhan ternak baik untuk hidup pokok, pertumbuhan, reproduksi dan produksi. Tiga faktor penting dalam kaitan penyediaan pakan bagi ternak puyuh adalah ketersediaan pakan harus dalam jumlah yang cukup, mengandung nutrient dan protein yang baik. Pakan dapat diperoleh dalam bentuk konsentrat dan hijauan, ketersediaan hijauan umumnya berfluktuasi mengikuti pola musim, dimana produksi hijauan melimpah dimusim hujan dan sebaliknya terbatas dimusim kemarau (Kalelado, 2007).

Salah satu hijauan yang dapat digunakan adalah daun ubi kayu. Potensi daun ubi kayu di Provinsi Riau sangat melimpah dimana hasil panen ubi kayu di Provinsi Riau terdapat 3.578 hektar dengan produksi 103.599 ton dimana potensi limbah daun ubi kayu sebanyak 383,7 ton (BPS, 2015) dengan potensi produksi daun ubi kayu segar sebesar 10-40\% dari tanaman ubi kayu atau setara dengan 10-40 ton/ha/tahun (Sirait, 2010). Selain produksinya yang melimpah daun ubi kayu memiliki kandungan protein berkisar antara $20-27 \%$ dari bahan kering. Kisaran ini disebabkan perbedaan varietas, kesuburan tanah dan komposisi campuran daun dan tangkai daun. Daun ubi kayu juga memiliki senyawa antinutrisi yang membatasi penggunannya. Menurut Sirait dan Simaniharuk (2010) bahwa pengolahan daun ubi kayu segar menjadi silase dengan cara fermentasi bahan pakan ubi kayu dapat menurun kandungan asam sianida. Silase adalah proses pengawetan hijauan pakan segar dalam kondisi anaerob dengan pembentukan atau penambahan asam.

Mulyasari (2011) menyatakan daun ubi kayu juga memiliki kandungan vitamin A, B1 dan
C yang cukup tinggi serta mengandung kalsium, fosfor dan zat besi. Vitamin adalah senyawa organik yang harus tersedia dalam jumlah sangat kecil untuk metabolisme jaringan normal. Yasin (1998) menyatakan semakin banyak kandungan vitamin A dalam ransum yang diberikan kepada unggas sedang bertelur, maka kualitas vitamin A dalam kuning telur semakin baik. Untuk memudahkan pemberian ransum berbahan daun ubi kayu dilakukan pengolahan pakan berbentuk mash. Pakan mash adalah pakan yang telah mengalami proses pengilingan sehingga ukuran partikel menjadi kecil (tepung) dan dapat dimakan ternak puyuh. Maradika (2006) menyatakan bahwa, penambahan tepung daun ubi kayu pada taraf $9 \%$ dapat meningkatkan produksi telur itik.

\section{MATERI DAN METODE}

Bahan yang digunakan dalam penelitian ini adalah 64 ekor puyuh betina fase pre layer Puyuh dilakukan adaptasi lingkungan dan pakan selama 1 minggu. Puyuh dimulai dengan pemberian perlakuan pada umur 4 minggu. Ransum yang digunakan terdiri dari: jagung halus, dedak halus, tepung ikan, bungkil kedele, minyak kelapa, kapur $\mathrm{CaCO} 3$ dan tepung silase daun ubi kayu dengan level yang berbeda. Alat yang digunakan dalam penelitian ini terdiri dari kandang baterai yang dimodifikasi dari kawat ram dengan ukuran panjang $40 \mathrm{~cm}$, lebar $20 \mathrm{~cm}$ dan tinggi $45 \mathrm{~cm}$. Peralatan lainnya yang digunakan adalah alat-alat kandang seperti tempat pakan dan minum, lampu sebagai penerang kandang, timbangan analitik, alat pembersih kandang, handspayer, kardus, alat tulis, kalkulator dan kamera.

Penelitian ini menggunakan metode eksperimen dengan Rancangan Acak Lengkap (RAL) terdiri dari : 4 perlakuan dan 4 kali ulangan. Setiap ulangan terdiri dari 4 ekor burung puyuh. Adapun perlakuan sebagai berikut:

$\mathrm{R}_{0}=$ Pakan mash tanpa penambahan tepung silase daun ubi kayu.

$\mathrm{R}_{1}=$ Pakan mash penambahan 3\% tepung silase daun ubi kayu.

$\mathrm{R}_{2}=$ Pakan mash penambahan $6 \%$ tepung silase daun ubi kayu.

$\mathrm{R}_{3}=$ Pakan mash penambahan $9 \%$ tepung silase daun ubi kayu.

Kebutuhan nutrisi puyuh petelur, kandungan nutrisi bahan pakan perlakuan disajikan pada Tabel 1 dan 2 dan komposisi dan kandungan nutrisi ransum disajikan pada Tabel 3 
Tabel 1. Kebutuhan nutrisi puyuh petelur

\begin{tabular}{lcc}
\hline Parameter & Satuan & Persyaratan \\
\hline Kadar air & $\%$ & Maks. 14,0 \\
Protein kasar & $\%$ & 20 \\
Lemak kasar & $\%$ & Maks. 7,0 \\
Serat kasar & $\%$ & Maks. 7,0 \\
Abu & $\%$ & Maks. 14,0 \\
Kalsium (Ca) & $\%$ & 3,0 \\
Fosfor (P) total & $\%$ & $0,40-1$ \\
Total aflatoksin & ug/kg & Maks. 40,0 \\
\hline
\end{tabular}

Sumber: Lesson and Summers (1997)

Tabel.2. Komposisi Nutrisi Bahan Pakan

\begin{tabular}{|c|c|c|c|c|c|c|}
\hline \multirow{2}{*}{ Bahan Pakan } & \multicolumn{6}{|c|}{ Kandungan Nutrisi } \\
\hline & PK & SK & $\overline{L K}$ & $\mathrm{Ca}$ & $P$ & ME \\
\hline Jagung Halus $^{1}$ & 5,83 & 3,43 & 4,30 & 0,06 & 0,02 & $3299^{2}$ \\
\hline Dedak Halus ${ }^{3}$ & 10,94 & 14,00 & 10,33 & $0,14^{5}$ & $0,60^{5}$ & 1453 \\
\hline Tepung Silase Daun Singkong 1 & 29,92 & 19,22 & 6,50 & 1,54 & 0,54 & 2624 \\
\hline Tepung Ikan & 61,00 & 1,00 & 9,00 & 5,50 & 2,80 & 3080 \\
\hline Bungkil Kedele ${ }^{4}$ & 30,30 & 6,00 & 5,07 & 0,90 & 0,67 & 2240 \\
\hline Minyak Kelapa & 0,00 & 0,00 & 60,41 & 0,00 & 0,00 & 8800 \\
\hline Kapur $\mathrm{CaCO} 3$ & 0,00 & 0,00 & 0,00 & 36,20 & 0,00 & 0,00 \\
\hline
\end{tabular}

Keterangan :

1. Analisis Laboratorium Kimia Perikanan Universitas Riau (2018)

2. Muhammad et al. (2014)

3. Nurbaiti (2015)

4. Wahju (2004)

5. Departemen Nutrisi dan Teknologi Pakan Fakultas Peternakan IPB Bogor (2015).

Tabel 3. Komposisi dan kandungan nutrisi ransum penelitian

\begin{tabular}{lcccc}
\hline \multirow{2}{*}{ Bahan Pakan } & \multicolumn{4}{c}{ Perlakuan } \\
\cline { 2 - 5 } & $\mathrm{T} 0$ & $\mathrm{~T} 1$ & $\mathrm{~T} 2$ & $\mathrm{~T} 3$ \\
\hline Jagung halus & 45,00 & 43,00 & 42,00 & 42,00 \\
Dedak halus & 15,00 & 14,00 & 13,00 & 12,00 \\
TSDS & 0,00 & 3,00 & 6,00 & 9,00 \\
Tepung Ikan & 22,00 & 22,00 & 21,00 & 19,00 \\
Bungkil Kedele & 8,00 & 8,00 & 8,00 & 8,00 \\
Minyak Kelapa & 4,00 & 4,00 & 4,00 & 4,00 \\
Kapur CaCO3 & 6,00 & 6,00 & 6,00 & 6,00 \\
Jumlah (\%) & 100,00 & 100,00 & 100,00 & 100,00 \\
\hline Komposisi nutrien & & & & \\
\hline Protein Kasar (\%) & 20,11 & 20,78 & 20,90 & 20,47 \\
EM (kkal/kg) & 2911,30 & 2909,51 & 2909,21 & 2912,50 \\
Serat Kasar (\%) & 4,34 & 4,71 & 5,10 & 5,52 \\
Lemak Kasar (\%) & 7,72 & 7,74 & 7,71 & 7,62 \\
Ca (\%) & 3,46 & 3,48 & 3,45 & 3,36 \\
P (\%) & 0,77 & 0,77 & 0,74 & 0,68 \\
\hline Biaya Pakan (Rp) & 6.910 & 6.880 & 6.840 & 6.790 \\
\hline Kerganyyyy
\end{tabular}

Keterangan: Disusun berdasarkan Tabel 1 dan 2 


\section{Prosedur Penelitian}

Adapun Prosedur penelitian disajikan pada Gambar 1 berikut:

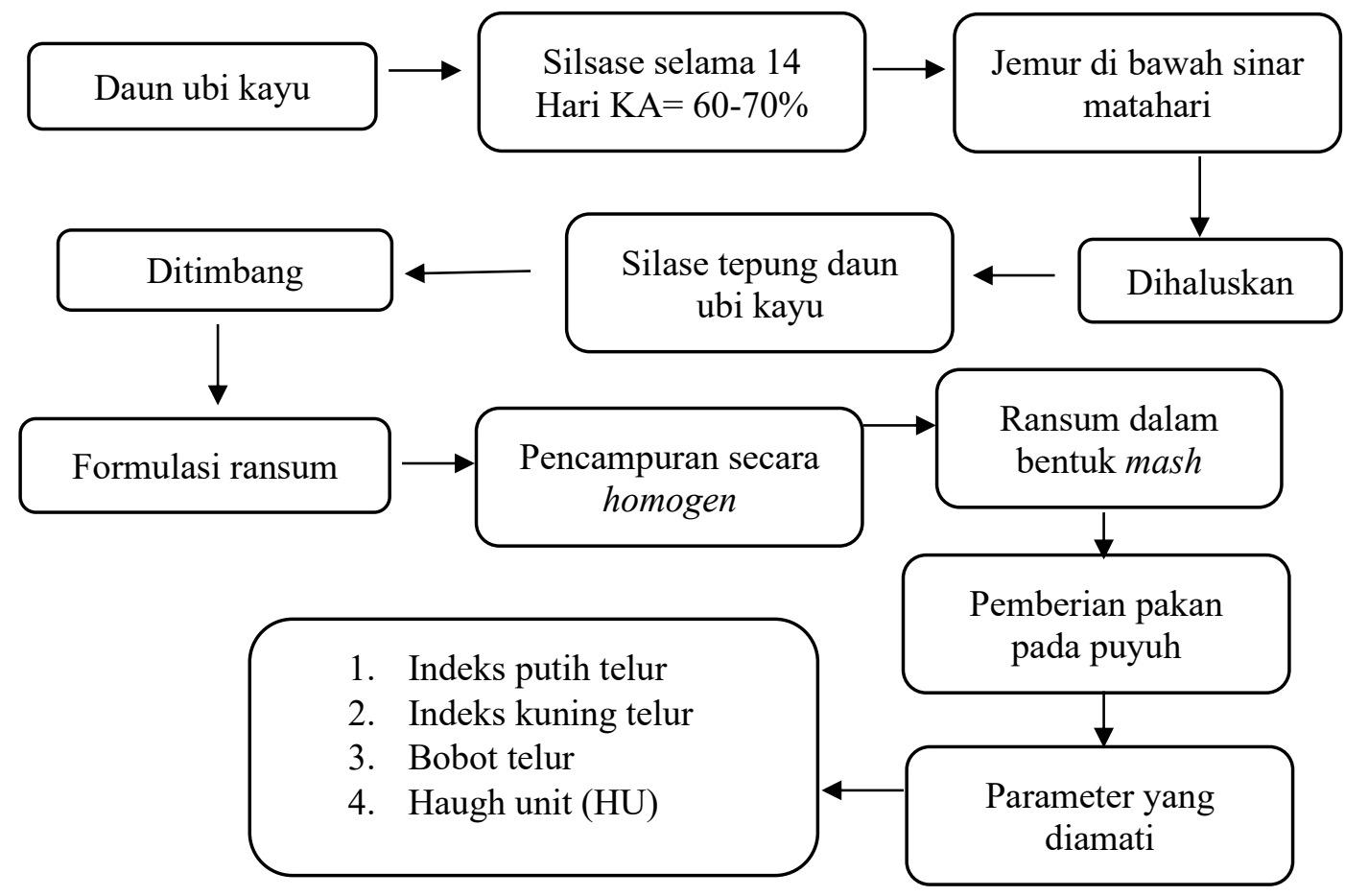

Gambar 1. Prosedur Penelitian

\section{HASIL DAN PEMBAHASAN}

\section{Indeks Putih Telur}

Indeks putih telur (albumen) selama penelitian dihitung berdasarkan perbandingan tinggi albumen dengan setengah jumlah dari panjang dan lebar albumen. Rata-rata Indeks putih telur (albumen) selama penelitian dapat dilihat pada Tabel 4 berikut ini:

Tabel 4. Rataan indeks putih telur puyuh menggunakan silase tepung daun ubi kayu

\begin{tabular}{cc}
\hline $\begin{array}{c}\text { Silase tepung daun } \\
\text { ubi kayu (\%) }\end{array}$ & Rataan \\
\hline 0 & $0,098 \pm 0,005$ \\
3 & $0,112 \pm 0,010$ \\
6 & $0,102 \pm 0,005$ \\
9 & $0,105 \pm 0,014$ \\
\hline Rata-rata & $0,104 \pm 0,009$ \\
\hline
\end{tabular}

Keterangan : Data adalah nilai rata-rata \pm Standar Deviasi (SD)

Tabel 4 memperlihatkan indeks putih telur dari telur burung puyuh yang diberi pakan silase tepung daun ubi kayu sampai 9\% menunjukkan perbedaan tidak nyata $(\mathrm{P}<0,05)$.
Tidak adanya perbedaan indeks putih telur dari perlakuan $0 \%$ - 9\% lebih dipengaruhi oleh kualitas nutrisi ransum dimana kandungan protein kasar semua perlakuan relatif sama yaitu $\pm 20 \%$, jadi meskipun terjadi peningkatan silase tepung daun ubi kayu tetap tidak mempengaruhi perubahan kualitas indeks putih telur. Hal ini sejalan dengan Mulyadi et al. (2017) pemberian tepung limbah udang fermentasi dalam ransum yang memiliki kandungan protein yang relatif sama tiap perlakuan belum mampu meningkatkan kualitas indeks putih telur.

Hasil rataan indeks putih telur untuk semua perlakuan relatif sama yaitu 0,104 dan tergolong baik. Sesuai BSN (2008) menyatakan bahwa indeks putih telur merupakan perbandingan antara tinggi putih telur dengan diameter rata-rata putih telur kental. Berdasarkan Standard Nasional Indonesia (SNI, 2008) menyatakan Indeks putih telur segar berkisar antara 0.050-0.174. Semakin tua umur telur maka diameter putih telur akan semakin lebar sehingga indeks putih telur akan semakin kecil. Perubahan putih telur disebabkan oleh pertukaran gas antara udara luar dengan isi telur melalui pori-pori kerabang telur dan penguapan air akibat dari lama penyimpanan, suhu, kelembaban dan porositas kerabang telur (Yuwanta, 2010). 
Indeks putih telur yang diperoleh dari penelitian ini lebih tinggi dibandingkan dari penelitian Saputra (2017) dengan pemberian daun pepaya dalam ransum terhadap kualitas telur pertama burung puyuh yang menghasilkan indeks putih telur 0,068-0,097. Hasil penelitian ini lebih rendah dari penelitian Mulyadi et al. (2017) yang menggunakan tepung limbah udang yang difermentasi dalam ransum menghasilkan indeks putih telur $0,16-0,17$. Hasil penelitian ini lebih tinggi dari penelitian Nasution (2017) yang menggunakan tepung limbah pepaya hingga level $15 \%$ dalam formulasi ransum menghasilkan indeks putih telur puyuh 0,076-0,097.

\section{Indeks Kuning Telur}

Indeks kuning telur (yolk) dihitung selama penelitian berdasarkan dengan mengukur dan menghitung perbandingan antara tinggi kuning telur dengan diameter yang diukur. Rata-rata Indeks kuning telur (yolk) selama penelitian dapat dilihat pada Tabel 5 berikut ini:

Tabel 5. Rataan indeks kuning telur puyuh menggunakan silase tepung daun ubi kayu

\begin{tabular}{cc}
\hline $\begin{array}{c}\text { Silase tepung daun } \\
\text { ubi kayu (\%) }\end{array}$ & Rataan \\
\hline 0 & $0,34 \pm 0,02^{\mathrm{a}}$ \\
3 & $0,39 \pm 0,01^{\mathrm{b}}$ \\
6 & $0,37 \pm 0,02^{\mathrm{ab}}$ \\
9 & $0,36 \pm 0,03^{\mathrm{ab}}$ \\
\hline Rata-rata & $0,37 \pm 0,02$ \\
\hline
\end{tabular}

Keterangan : Data adalah nilai rata-rata; Superskrip huruf yang berbeda pada kolom yang sama menunjukkan pengaruh berbeda nyata $(\mathrm{P}<0,05)$; \pm Standar Deviasi (SD)

Berdasarkan Tabel 5 memperlihatkan indeks kuning telur dari telur burung puyuh yang diberi pakan silase tepung daun ubi kayu menunjukkan perbedaan nyata $(\mathrm{P}<0,05)$. Perlakuan $0 \%$ menghasilkan indeks kuning telur yang sama dengan perlakuan $6 \%$ dan $9 \%$. Hal ini diduga karena kandungan protein yang terkandung dalam silase daun ubi kayu bisa mencukupi kebutuhan terhadap proses terbentuknya kuning telur. Triastiarti et al. (2017) menyatakan bahwa kuning telur tersusun atas lemak dan protein, membentuk lipoprotein yang disintesis oleh hati dengan pengaruh esterogen. Indeks kuning telur dipengaruhi oleh protein, lemak dan asam amino esensial yang terkandung dalam ransum.
Faktor yang mempengaruhi indeks kuning telur adalah ketersediaan protein dan asam amino didalam pakan dapat mempengaruhi indeks kuning telur, karena protein dan asam amino merupakan komponen pembentuk membran vitelin yang berfungsi menahan kuning telur sehingga indeks kuning telur bergantung dari asupan protein yang dikonsumsi oleh ternak. Selain itu faktor yang mempengaruhi peningkatan indeks kuning telur adalah kelembaban dan suhu lingkungan. Suhu dan kelembaban pada penelitian ini diperoleh berkisar antara suhu 27$32^{\circ} \mathrm{C}$ dan kelembaban $80-90 \%$. Hal ini diduga mempengaruhi pembentukan indeks kuning telur pada proses reproduksi dan metabolisme dari burung puyuh. Menurut Suhaely (2008), menyatakan bahwa suhu lingkungan yang optimal untuk puyuh adalah $20-30^{\circ} \mathrm{C}$ dengan kelembaban lingkungan antara $30-80 \%$.

Ransum yang diberi silase tepung daun ubi kayu dapat meningkatkan kualitas indeks kuning telur, hal ini dikarenakan keberhasilan silase meningkatkan protein kasar di dalam ransum. Hal ini sesuai dengan pendapat Wilson (2007) protein pakan akan mempengaruhi viskositas telur yang mencerminkan kualitas interior telur, selanjutnya dapat mempengaruhi indeks kuning telur. Kualitas membran vitelin dan pakan dengan kandungan protein yang memenuhi kebutuhan memberikan pengaruh besar bagi indeks kuning telur (yolk index) (Argo et al., 2013).

Rataan indeks kuning telur selama penelitian, yaitu berkisar antara 0,34-0,39 menurut Standard Nasional Indonesia (SNI 3926:2008) menyatakan bahwa indeks kuning telur segar berkisar antara 0,33-0,52. Hasil penelitian ini lebih rendah dibandingkan dengan penelitian Saputra (2017) yang menggunakan tepung pepaya dalam ransum mendapatkan hasil rataan indeks kuning telur $0,39-0,44$; juga lebih rendah dibandingkan penelitian Lestari et al. (2016) yang pemeliharaan dengan menambahkan cahaya monokromatik menghasilkan indeks kuning telur yaitu $0,41-0,63$.

\section{Bobot Telur}

Bobot telur puyuh merupakan jumlah 1 butir telur puyuh yang dinyatakan dalam gram setelah dilakukan penimbangan bobot telur yang diproduksi setiap hari selama 4 minggu. Rata-rata bobot telur puyuh selama penelitian dapat dilihat pada Tabel 6 bawah ini: 
Tabel 6. Rataan bobot telur puyuh menggunakan silase tepung daun ubi kayu

\begin{tabular}{cc}
\hline $\begin{array}{c}\text { Silase tepung daun } \\
\text { ubi kayu (\%) }\end{array}$ & Rataan (g/butir) \\
\hline 0 & $8,66 \pm 0,27^{\mathrm{b}}$ \\
3 & $8,08 \pm 0,24^{\mathrm{a}}$ \\
6 & $8,65 \pm 0,38^{\mathrm{b}}$ \\
9 & $8,96 \pm 0,25^{\mathrm{b}}$ \\
\hline Rata-rata & $8,58 \pm 0,28$
\end{tabular}

Keterangan : Data adalah nilai rata-rata; Superskrip huruf yang berbeda pada kolom yang sama menunjukkan pengaruh berbeda sangat nyata $(\mathrm{P}<0,01) ; \pm$ Standar Deviasi (SD)

Tabel 6. menunjukkan bobot telur dari burung puyuh yang diberi pakan silase tepung daun ubi kayu menunjukkan perbedaan sangat nyata $(\mathrm{P}<0,01)$. Perlakuan $0 \%, 6 \%, \quad 9 \%$ menghasilkan bobot telur yang relatif sama. Hal ini diduga karena bahan penyusun ransum yang digunakan relatif sama, sehingga kandungan nutrisi juga memberikan efek yang relatif sama terhadap bobot telur puyuh. Perlakuan silase $3 \%$ menghasilkan berat telur yang lebih rendah dibandingkan dengan perlakuan lain, hal ini kemungkinan disebabkan karena kelompok puyuh pada perlakuan ini memiliki umur bertelur pertama yang belum seragam sehingga berpengaruh terhadap berat telur yang dihasilkan.

Syahada (2016) menyatakan bahwa bobot telur ditentukan oleh banyak faktor antara lain genetik, dewasa kelamin, umur, beberapa obatobatan dan beberapa zat makanan dalam ransum. Listiyowati dan Rospitasari (2009) menambahkan bahwa bobot telur merupakan sifat kuantitatif yang dapat diturunkan. Jadi, jenis pakan, jumlah pakan, lingkungan kandang, serta besar tubuh induk sangat mempengaruhi bobot telur. Bobot telur juga sangat dipengaruhi oleh masa bertelur. Telur pada produksi pertama dari siklus berbobot lebih rendah dibandingkan telur berikutnya pada siklus yang sama. Dengan kata lain, bobot telur semakin bertambah seiring dengan bertambahnya umur induk.

Rataan bobot telur yang diperoleh selama penelitian 8.08-8.96 lebih rendah dibandingkan penelitian Claudia (2014) yang menggunakan penambahan rimpang kunyit, temulawak, dan temu putih dalam ransum menghasilkan bobot telur 10.0-10.67 (g/butir), juga lebih rendah dibandingkan penelitian Nuraini et al. (2012) dengan menggunakan pakan mengandung produk fermentasi dengan Neurospora crassa menghasilkan bobot telur puyuh 9,94-10,29 ( $\mathrm{g} /$ butir).

\section{Haugh Unit (HU)}

Haugh unit merupakan satuan nilai dari putih telur dihitung dengan cara logaritma terhadap tinggi putih telur kental dan kemudian ditransformasikan dalam nilai koreksi dari fungsi berat telur: Haugh unit $=100 \log (\mathrm{H}+7,75-$ $\left.1 \mathrm{~W}^{0,37}\right)$. Rata-rata nilai haugh unit selama penelitian dapat dilihat pada Tabel 7 di bawah ini.

Tabel 7. Rataan haugh unit (HU) telur puyuh menggunakan silase tepung daun ubi kayu

\begin{tabular}{cc}
\hline $\begin{array}{c}\text { Silase tepung daun ubi } \\
\text { kayu (\%) }\end{array}$ & Rataan \\
\hline 0 & $76,39 \pm 0,13^{\mathrm{b}}$ \\
3 & $77,11 \pm 0,40^{\mathrm{b}}$ \\
6 & $76,55 \pm 0,23^{\mathrm{b}}$ \\
9 & $74,98 \pm 1,54^{\mathrm{a}}$ \\
\hline Rata-rata & $76,26 \pm 0,58$ \\
\hline
\end{tabular}

Keterangan : Data adalah nilai rata-rata; Superskrip huruf yang berbeda pada kolom yang sama menunjukkan pengaruh berbeda nyata $(\mathrm{P}<0,05) ; \pm$ Standar Deviasi $(\mathrm{SD})$.

Berdasarkan Tabel 7 memperlihatkan haugh unit dari telur burung puyuh yang diberi pakan silase tepung daun ubi kayu menunjukkan perbedaan nyata $(\mathrm{P}<0,05)$. Perlakuan 9\% menghasilkan haugh unit (HU) lebih rendah dibandingkan dengan $0 \%, 3 \%$, dan $6 \%$. Hal ini diduga disebabkan karena perbedaan tinggi albumen yang diperoleh, tinggi albumin pada penelitian ini yaitu perlakuan $9 \%(0,47)$, perlakuan $0 \%, 3 \%$, dan $6 \%(0,46),(0,50$,$) dan$ $(0,47)$. Mulyadi et al., (2017) menyatakan ada korelasi positif antara nilai albumin dengan nilai haugh unit, yaitu semakin tinggi nilai albumin maka semakin tinggi nilai haugh unit yang dihasilkan.

Kecukupan asupan protein dalam pakan untuk ternak merupakan salah satu faktor yang mempengaruhi kualitas putih telur (mucin dan lisosim) sehingga dapat memberikan hasil yang baik terhadap nilai HU. Hal ini sesuai dengan pendapat Amin et al. (2015) menyatakan bahwa faktor yang dapat mempengaruhi nilai HU adalah tinggi albumin, nutrisi pakan, asupan protein dan berat telur. Rendahnya nilai HU pada perlakuan silase $9 \%$ dibandingkan dengan perlakuan lainnya diduga disebabkan terjadi proses penyimpanan telur yang terlalu lama sebelum proses analisa. Faktor-faktor lain yang mempengaruhi nilai haugh unit diantaranya adalah umur puyuh dan lama penyimpanan telur. Semakin lama 
penyimpanan telur maka nilai haugh unit akan semakin menurun dan nilai haugh Unit akan menurun dengan bertambahnya umur ayam (Yuwanta, 2010). Hasil penelitian termasuk dalam kategori A (HU) 79-55. Menurut Yuwanta (2010) menyatakan bahwa dalam standar United State Departement of Agriculture (USDA) kualitas telur pada nilai $\mathrm{HU}$ diklasifikasi ke dalam 4 kelas yaitu: (1) Kelas AA memiliki nilai HU lebih dari 79, (2) Kelas A memiliki nilai HU antara 79-55, (3) Kelas B memiliki nilai HU antar 55-31, (4) Kelas C memiliki nilai HU kurang dari 31.

Nilai HU pada penelitian lebih tinggi dari yang dilaporkan oleh Syahada (2016) yang menambahkan tepung limbah udang dalam ransum komersial, dimana Nilai HU yang didapatkan untuk telur puyuh adalah 61,33. Namun penelitian ini lebih rendah dibandingkan dengan Amin et al. (2015) dengan penambahan ekstrak kunyit dalam air minum mendapat nilai haug unit 78,90-86,50. Nilai HU pada penelitian ini juga lebih rendah dibandingkan penelitian Sumadja et al. (2019) menggunakan ransum puyuh dengan penambahan bungkil buah Kepayang hingga taraf 7,5\% menghasilkan nilai HU sebesar 88,95 - 89,27.

\section{KESIMPULAN}

Kesimpulan dari penelitian ini adalah penggunaan silase tepung daun ubi kayu dalam formulasi ransum puyuh sampai $9 \%$ belum mampu meningkatkan indeks putih telur, indeks kuning telur, dan haugh unit tetapi dapat meningkatkan bobot telur, selanjutnya perlakuan terbaik yaitu dengan penambahan silase tepung daun ubi kayu pada taraf 3\% karena dapat meningkatkan indeks putih telur, indeks kuning telur, dan haugh unit (HU).

\section{DAFTAR PUSTAKA}

Abidin, Z. 2003. Meningkatkan Produktifitas Ayam Ras Pedaging. Agromedia Pustaka. Jakarta.

Amin, N.S., Anggraeni dan E. Dihansih. 2015. Pengaruh penambahan larutan ekstrak kunyit (Curcuma domestica) dalam air minum terhadap kualitas telur burung puyuh. Jurnal Peternakan Nusantara 1 (2) : 115-125.

BPS. Badan Pusat Statistik. 2015. Data Produksi dan Produktivitas Perkebunan Daun Ubi Kayu
https://www.bps.go.id/linkTableDinam is/view/id/880.

BSNI. Badan Standar Nasional Indonesia. 2008. Telur Ayam Konsumsi. 12983_SNI 3926:2008.

Claudia, R., J. L. P. Saerang., F. J. Nangoy and S. Laatung. 2014. Penambahan Rimpang Kunyit (Curcuma domestica Val) Temulawak (Curcuma xanthorriza Roxb) dan Temu Putih (Curcuma zedoaria Rosc) dalam Ransum Komersil terhadap Kualitas Telur Burung Puyuh (Coturnix-coturnix japonica). Jurnal Zootek 1: 106-113.

Kalelado, L. 2007. Evaluasi Kualitas Silase Rumput Sudan (Sorghum sudanense) pada Penambahan Berbagai Macam Aditif Karbohidrat Mudah Larut. Thesis. Pasca Serjana Program Studi Ilmu Peternakan. Universitas Gadjah Mada, Yogyakarta.

Lestari,W.T., S. Tana dan S. Isdadiyanto. 2016. Indeks kuning telur dan nilai haugh unit telur puyuh (Coturnix coturnix japonica $\mathrm{L}$.) hasil pemeliharaan dengan penambahan cahaya monokromatik. Buletin Anatomi dan Fisiologi 24 (1) : 42 - 49.

Leeson, S and J. D. Summers 1997. Nurtision of the chicken. 4 edition University Books. Canada.

Listiyowati, E., dan K. Rospitasari. 2009. Beternak Puyuh Secara Komersial. Edisi Revisi. Penebar Swadaya. Jakarta.

Maradika, G. 2006. Perubahan Warna Kuning Telur Itik Lokal dengan Penambahan Tepung daun Kaliandra (Calliandra alothyrsus) dan Daun Singkong (Manihot esculenta Crantz) pada Pakan. Skripsi. Program Studi Teknologi Produksi Ternak, Fakultas Peternakan, Institut Pertanian Bogor. Bogor.

Muhammad, M. 2012. Pengaruh Bentuk Telur dan Bobot Telur terhadap Jenis Kelamin, Bobot Tetas dan Lama Tetas Burung Puyuh. Skripsi. Bagian Produksi Ternak, Fakultas Peternakan. Universitas Brawijaya. Malang.

Mulyadi, A., E. Suprijatna, and U. Atmomarsono. 2017. Pengaruh Pemberian Tepung Limbah Udang Fermentasi dalam Ransum Puyuh terhadap Kualitas Telur. Agripet. 17 (12) : 95-103. 
Nasution, A. S. 2017. Kualitas telur pertama burung puyuh (Coturnix coturnix javonica) dengan pemberian tepung daun pepaya (Carica papaya L.) dalam ransum. Jurnal Peternakan 1 (1) : $34-41$.

Nuraini, S. dan S. A Latif. 2012. Penampilan dan kualitas telur puyuh yang diberi pakan mengandung produk fermentasi dengan Neurospora crassa. Jurnal Peternakan Indonesia 14 (2) : 385 - 391.

Saputra, A. 2017. Kualitas Telur Pertama Burung Puyuh (Coturnix coturnix javonica) dengan Pemberian Tepung Daun Pepaya (Carica papaya L.) dalam Ransum. Skripsi. Fakultas Peternakan Program Studi Peternakan Universitas Muhammadiyah Tapanuli Selatan.

Sirait, J., dan K. Simanihuruk. 2010. Potensi dan pemamfaatan daun ubi kayu dan ubi jalar sebagai sumber pakan ternak ruminansia kecil. Wartazoa 20 (2) : 75 -84.

Suhaely, A. 2008. Perancangan Fasilitas Fisik Usaha Ternak Puyuh Skala Komersial di Kecamatan Ranca Bungur, Kabupaten Bogor, Jawa Barat. Skripsi. Institut Pertanian Bogor. Bogor.
Sumadja, W.A., Resmi dan M. Atdhenan. 2019. Penggunaan bungkil kepayang (Pangium edule Reinw) dalam ransum terhadap kualitas telur puyuh (Coturnix coturnix japonica). Seminar Nasional Pakar ke 2 Pp.: 1-10.

Syahada, F. 2016. Pengaruh penambahan tepung limbah udang dalam ransum terhadap kualitas telur puyuh. Skripsi. Jurusan Ilmu Peternakan Universitas Islam Negeri Sultan Syarif Kasim Riau. Pekanbaru.

Wahju, J. 2004. Ilmu Nutrisi Unggas. Gadjah Mada University Presss. Yogyakarta.

Wilson, B. J., 2007. The performance of male ducking given starter diets with different concentration of energy and protein. J. British Poult. Sci. $16: 625-657$.

Yasin, S. 1988. Fungsi dan Peranan Zat-zat Gizi dalam Ransum Ayam Petelur. PT Melton Putra. Jakarta. Hal. 58-62.

Yuwanta, T. 2010. Telur dan Kualitas Telur. Gadjah Mada University Press. Yogyakarta. 